Contato

Faculdade de Filosofia, Letras e Ciências Humanas

R. Luciano Gualberto, 403 05508-060 - São Paulo - SP

lal@usp.br

\section{A CARTA MUNDUS NOVUS DE VESPUCCI E A LENDA DO HOMEM NATURAL DE ROUSSEAU}

\section{Luiz Antônio Lindo*}

Universidade de São Paulo

\title{
Resumo
}

O artigo procura mostrar que, na carta Mundus Novus, de Vespucci, delineia-se um perfil de tipo humano no qual a variabilidade individual e de estágio civilizatório pode ser reduzida, por meio de abstração, à forma geral do "selvagem" voltado para a exploração hedonista do seu meio e como tal imune a todo e qualquer freio que lhe imponha o sacrifício esperado na edificação da vida civilizada. Esse perfil parece casar com a ideia do "selvagem" que habita o interior humano e supostamente alimenta o sentimento de existência como o entendia Rousseau.

\section{Palavras-chave}

Vespucci - o selvagem em Mundus Novus - a lenda do homem natural.

* Doutor em Letras Clássicas e professor-doutor de Filologia Românica no Departamento de Letras Clássicas e Vernáculas da Faculdade de Filosofia, Letras e Ciências Humanas. 
rev. hist. (São Paulo), n. 172, p. 279-297, jan.-jun., 2015 http://dx.doi.org/10.11606/issn.2316-9141.rh.2015.98756

\section{VESPUCCI'S LETTER MUNDUS NOVUS AND THE LEGEND OF ROUSSEAU'S NATURAL MAN}

Contact Universidade de São Paulo Faculdade de Filosofia, Letras e Ciências Humanas R. Luciano Gualberto, 403 05508-060 - São Paulo - SP lal@usp.br

\section{Luiz Antônio Lindo}

Universidade de São Paulo

\section{Abstract}

The paper aims to apprehend in the letter Mundus Novus of Vespucci a human profile in which the individual variability and the level of civilization can be reduced, through abstraction, to the general form of the "savage", determined to exploit hedonistically the environment, making himself exempt from any barrier found in the edification of the civilized life. This profile seems akin to the idea of the "savage" plausibly devised by Rousseau as a source of the feeling of existence.

\section{Keywords}

Vespucci - the savage in Mundus Novus - the legend of the natural man. 
O primeiro homem é também o último na religião da Bíblia ou na ontologia clássica. Equivale isto a dizer que variações observadas em sua forma de existir singularmente ou como espécie são apenas modos de ser não substanciais, meras alterações circunstanciais indiferentes na definição do humano. Nesse sentido, nada pode ser acrescentado à perspectiva bíblica sobre o primeiro homem que contrarie o fato de ele ter sido criado completo pelas mãos de Deus. Na metafísica clássica do estagirita, o conceito de homem é o de uma substância composta (synolos) de alma e corpo, em cujo primeiro elemento do composto, a alma, acha-se a sede da razão e o atributo responsável pela diferença específica de sua espécie, pela qual é ele definido como um ser racional. Vale registrar que a concepção peripatética, ao encontrar-se com a bíblica, deu origem a uma dicotomia, de modo a ser possível pensar no homem sob dois ângulos que dizem muito sobre a concepção do humano na cultura ocidental: pelo primeiro, tem-se conhecimento do homem essencial, detentor da faculdade racional; pelo segundo, descobre-se o homem real, forçado a viver sob o peso do pecado de Adão.

Em contraposição às concepções entre si complementares da Bíblia e da ontologia clássica, uma ideia distinta de homem foi-se cristalizando nos tempos modernos, extraída em parte da reflexão e da introspecção e em parte da observação de exemplos concretos do viver humano. Na verdade, duas ideias novas desenvolveram-se no pensamento europeu, aproximadamente entre os séculos XV e XVII, por influência dos humanistas e em virtude da internacionalização da cultura ocidental tornada possível pelos descobrimentos. A primeira ideia, marcada pela moral religiosa própria da época, põe em dúvida a unidade da espécie humana. ${ }^{1}$ Não é difícil ver o quanto contribuiu para isso o conhecimento adquirido com a descoberta da América e o encontro dos "selvagens", assim chamados por viverem à revelia dos hábitos e costumes característicos da civilização. ${ }^{2}$ Como quer que seja, as controvérsias antropológicas e doutrinárias que tiveram origem no contato

\footnotetext{
1 "Acreditou-se por muito tempo que só havia uma humanidade, a posteridade dos filhos de Noé - ela mesma dividida em duas partes, a cristandade, dum lado, a terra pagã, do outro". HAUSER, H. La modernité du XVIe siècle. Paris: Librairie Armand Colin, 1963, p. 33.

2 Como mostra G. Gliozzi, foi Paracelso (1493-1541) o introdutor da tese poligenista inspirada na realidade americana, ao apropriar-se dos relatos dos conquistadores nos quais se assinalava a animalidade do índio. "É precisamente este aspecto, diz ele, que induz Paracelso a tirar proveito das afirmações dos conquistadores sobre a animalidade dos índios para transformá-las numa verdadeira teoria poligênica." In: GLIOZZI, G. Adam et le Nouveau Monde - La naissance de l'anthropologie comme idéologie coloniale: des généalogies bibliques aux théories raciales (1500-1700). Tradução de A. Estève e P. Gabellone. Paris: Théétete Éditions, 2000, p. 253.
} 
com os povos bizarros do Novo Mundo foram desde logo enfrentadas com suma perícia e profundidade nos escritos de polemistas como Las Casas, Juan Ginés de Sepúlveda e Francisco de Vitoria, para citar alguns teólogosfilósofos que viam no indígena americano florescer as mesmas qualidades do homem civilizado e se mostravam, portanto, avessos a negar a ideia da descendência de uns e outros do primeiro homem, Adão. Outros cronistas e escritores europeus de diferentes matizes culturais, particularmente Jean de Léry, Bodin e Montaigne, ajudaram, por sua vez, a dar uma ideia enaltecedora do selvagem. Montaigne especialmente chama à América "um mundo infantil", ${ }^{3}$ um rótulo que haveria de ter consequências notáveis na difusão duma consciência de humanidade dividida em seções díspares entre si, conquanto essa divisão, dada a natureza da classificação sugerida, fosse passível de solução, à medida que a maturação da seção atrasada o permitisse.

Uma outra ideia inovadora surgida no período, qual seja a do progresso $^{4}{ }^{4}$ calcada na posse dum conhecimento técnico superior ao dos antigos, permitia considerar a construção dum "mundo novo" supostamente do interesse de todos os povos indistintamente. A confiança num futuro no qual as diferenças humanas fossem reduzidas ao mínimo significava, por sua vez, atingir um patamar de humanidade com um grau de moralidade como nunca antes houvera.

\footnotetext{
3 A concepção duma América cronologicamente associada à infância tomou corpo a partir dos trabalhos de Loys Le Roy, publicados no terceiro quartel do século XVI, como nota G. Gliozzi, ele mesmo em parte responsável pelo crédito devido a Le Roy nessa matéria. Eis o que diz o historiador italiano sobre o assunto: "A ideia do Novo Mundo como 'mundo infantil' que Le Roy introduzia na cultura moderna, após ter optado pela concepção cíclica da história, estava destinada a representar um momento crucial na reflexão filosófica no Novo Mundo". In: GLIOZZI, G. Differenze e uguaglianza nella cultura europea moderna. Nápoles: Vivarium, 1993, p. 200-201.

4 "Ela deveria naturalmente sair da oposição, tantas vezes mencionada, entre o saber antigo e as descobertas que os novos métodos tinham tornado possíveis." HAUSER, H., op. cit., p. 35. Com maior precisão, P. Rossi mostra que a imagem "moderna da ciência", a qual desempenha um papel decisivo na consolidação duma certa ideia de progresso, "tem origens históricas precisas". Ausente nas culturas primitivas, "ela vem à luz na Europa, entre meados do século XVI e o fim do século XVIII, como o produto mais típico da civilização ocidental moderna". (ROSSI, P. Naufrágios sem espectador, a ideia de progresso. São Paulo: Ed. Unesp, 1996, p. 47). Essa ideia, salienta o historiador italiano, será ainda reforçada com o desenvolvimento da ciência moderna, mormente a partir do século XVII, até entrar em crise no final do XIX, em consequência da crítica movida ao positivismo, e exacerbada no início do XX, tornada possível em virtude da associação da técnica com o desastre da guerra e seus efeitos catastróficos no destino da humanidade.
} 
Aparentemente, a crença no progresso não prosperou tanto quanto a da unidade do cosmion humano. ${ }^{5}$ Vale lembrar que antes mesmo do encontro do "selvagem" pelo homem civilizado, ${ }^{6}$ era já esta unidade acalentada nas discussões sobre a posição do homem no cosmo levadas a efeito por vários humanistas. Pico della Mirandola, destacando-se a propósito com a sua Oratio de Hominis Dignitate, sustentara a tese de que o homem, ao contrário do que pensavam os antigos - mercê de sua visão teológica - não está no centro do mundo nem constitui um microcosmo, ${ }^{7}$ mas tem o poder de compartilhar as propriedades de todos os outros seres, desde que faça uso de sua vontade livre. Ser livre significa, por sua vez, não ter a vida determinada estritamente pelas necessidades ditadas pela natureza. ${ }^{8}$ Encontrar um homem que é feliz por saber usar sua liberdade é dar-se conta da essência humana em sua forma mais pura, como haveria de entender Pico. Eis um trecho da Oratio que ilustra este ponto:

\footnotetext{
Trata-se aqui da unidade moral e política e não propriamente da unidade de origem propugnada pela tese monogenista, cuja disputa com a tese oposta do poligenismo foi exposta de maneira exemplar por GLIOZZI, G. Adam et le Nouveau Monde, op. cit. Como mostra este autor, às p. 283-290, uma vez que o mito do monogenismo "assume o papel de justificação ideológica fundamental" em T. Campanella, particularmente quando este defende a monarquia universal cristã, é lícito, sob esta consideração, associar o monogenismo da criação à ideia de uma possível unificação política de todos os povos. De qualquer modo, o que se tem em vista aqui aponta antes para o que A. Agnolin chama de "construção da igualdade", ou seja, uma forma de pensar o homem deflagrada no Renascimento, tendente a edificar uma civilização específica no âmbito dum processo histórico-cultural marcado pelos ideais da modernidade. Segundo Agnolin, "o século XVI representa o momento mais significativo de um percurso que, constituindo os homens na base de uma mesma estrutura subjetiva - o subjectum homo, preconizado já por Dante e fortalecido por Petrarca: isto é, só existe o Homem e cada característica, que nós hoje definiríamos de cultural, social, histórica etc., representa somente determinados aspectos dessa única entidade - e das mesmas representações, encaminha-se em direção à construção da Igualdade (e vale destacar que esta última é o resultado de uma perspectiva civilizacional, na medida em que o seu oposto, isto é, o particularismo, representa o resultado mais próprio de uma perspectiva culturalista, não por acaso própria e tardiamente oitocentista)". In: AGNOLIN, A. Jesuítas e selvagens: A negociação da fé no Encontro Catequético-Ritual Americano-Tupi (séculos XVI-XVII). São Paulo: Humanitas, p. 477.

${ }^{6}$ Foi no seio da civilização renascentista que amadureceu o pensamento em torno da categoria "selvagem". Vide AGNOLIN, A., op. cit., p. 483.

7 Na sua forma mais simples o microcosmismo se expressa na "ideia de que o homem contém em seu ser todos os elementos em que o mundo consiste". Ter todo o mundo em escala menor dentro de si faria dele um microcosmo. Vide ALLERS, R. Microcosmus from Anaximandros to Paracelsus. In: Traditio, II, 1944, p. 321.

${ }^{8}$ É interessante notar que a possibilidade de o homem poder escolher a vida que quer levar haverá de ser confirmada parcialmente na descrição encontrada em cronistas americanos acerca dos costumes do "selvagem".
} 
Finalmente, o melhor dos artesãos ordenou que a criatura a quem Ele fora capaz de dar nada próprio a si mesmo tivesse a posse conjunta de tudo que fosse peculiar a cada uma das diferentes espécies de seres. Tomou, portanto, o homem como uma criatura de natureza indeterminada e, tendo-lhe conferido um lugar no meio do mundo, a ela dirigiu-se desta maneira: "Nem uma habitação fixa, nem uma forma exclusivamente tua, nem alguma função peculiar a ti te demos, Adão, com o fim de que, em conformidade com a tua aspiração e com o teu julgamento, pudesses ter e possuir qualquer habitação, forma e funções que tu mesmo desejasses. A natureza de todas as outras coisas é limitada e mantida dentro dos limites das leis prescritas por Nós. Tu, não sujeito a nenhum limite, segundo a tua própria vontade livre, em cujas mãos te pusemos a ti, deverá ordenar por ti mesmo os limites de tua natureza. Pusemos-te no centro do mundo a fim de que pudesses de lá observar mais facilmente o que existe no mundo. Fizemos-te nem do céu nem da terra, mortal ou imortal, para que com liberdade de escolha e com honra, como se fosses o realizador e modelador de ti mesmo, pudesses dar um feitio a ti mesmo na forma que preferires. Terás a capacidade de degenerar nas formas mais baixas de vida, que são animalescas. Terás a capacidade, a partir do julgamento de tua alma, de renascer nas formas mais altas, que são divinas".

A amplidão da natureza humana com as suas múltiplas possibilidades, concebida por Pico, implica ver o homem como o autor de si mesmo, um segundo criador apenas situado abaixo do primeiro que lhe conferiu as capacidades exclusivas que possui no reino da natureza. Mas uma criatura que se faz a si mesma requer as condições para que possa moldar-se a seu bel prazer. Ela deve encontrá-las na posse duma liberdade irrestrita, ou seja, numa capacidade de agir sem sofrer a privação de movimentos imposta de fora e de superar toda coerção ou ordem que a obrigue a obedecer contra a sua vontade. ${ }^{10}$ Que um tal desejo surja e avulte como os sonhos que se desenrolam na imaginação é compreensível; que ele possa realizar-se a bel prazer é outra história. Uma olhadela na situação concreta do homem civilizado bastaria para entender que uma existência sem peias não seria possível nem porventura desejável nos quadros da cultura efetivamente adotada

\footnotetext{
9 PICO DELA MIRANDOLA. Oration on the dignity of man, 3. Tradução inglesa de E. L. Forbes. In:CASSIRER, Ernst; KRISTELLER, Paul Oskar; RANDALL JR., John Herman (ed.). The Renaissance philosophy of man. Chicago: The University of Chicago Press, 1948.

${ }^{10}$ Como se pode verificar, o nexo entre o pensamento dum Pico e o dum pensador moderno sempre evocado por seu espírito "libertário" como Rousseau revela-se em torno da afirmação da liberdade como o pressuposto duma concepção revolucionária do homem. Como diz G. Gliozzi, “a importância atribuída à liberdade humana permite a Rousseau estender a física da alma do âmbito restrito do indivíduo para a história da espécie" (GLIOZZI, G. Differenze e uguaglianza nella cultura europea moderna, op. cit., p. 392).
} 
pelas nações. Antes, o que prevalece nesses domínios é a certeza de que os benefícios duma vida dedicada ao interesse do bem comum, conquanto amuada pelos sacrifícios pessoais nela implícitos, é um fator decisivo na equação com que os homens calculam a oportunidade de adotar uma vida plena. De qualquer modo, porém, sempre seria possível forjar no íntimo de si mesmo um programa de vida tendente a tornar hábito um modo de ser e entender o mundo exterior a partir da sensibilidade, vale dizer, a partir das paixões que movem a alma humana. Nada impede que, entregue aos devaneios reservados ao interior de si mesmo ou às fantasias acerca duma existência além dos muros da cidade conhecida, o indivíduo possa colher subsídios para continuar a sua caça à liberdade redentora dos males do quotidiano. Nessa perspectiva, a força do sonho era pois tão grande que este acabou sendo proclamado factível e afinal narrado por uma personagem concebida por Jean-Jacques Rousseau. O vigário saboiano, essa personagem, será porventura o primeiro moderno a varar com sucesso as profundezas ignotas da alma sequiosa de liberdade, a partir do momento em que, esmiuçando o seu interior mais íntimo, encontra as condições para uma vida plena, perguntando-se para si: "De que se goza numa tal situação? De nada exterior a si mesmo, de nada senão de si mesmo e de sua própria existência, enquanto esse estado durar, a gente se basta a si mesmo tal qual Deus."11 Mas buscar, como faz o vigário, o gozo da liberdade dentro de si significa inebriar-se com o vinho produzido pelo próprio ego, quando o que se deseja, se a gente se faz adepto do gozo prometido ao homem completo piquiano, de carne e osso e simultaneamente membro da sociedade, é que nem os prazeres da alma nem os do corpo sejam negados. Como se pressupõe em tal caso, é preciso, para satisfazer o corpo, baixar até onde reside a animalidade. Isto, porém, se levado ao ponto máximo, haverá de contrariar o pudor e os requisitos morais do homem racional civilizado. Pois desejar estar na condição de quem livremente se satisfaz parece ser demasiado brutal para que sobre essa condição não se façam pesar as prescrições e sanções que costumam ser adotadas a fim de garantir o decoro e a paz social. Gozar do corpo em forma extrema, como pressupõe a posse da liberdade plena, requer afinal uma transformação moral que o homem civilizado parece não estar preparado para fazer. Mas o que se pode dizer sobre o que se passa além das fronteiras das nações policiadas, há pouco cruzadas pelos descobridores? Encontra-se

\footnotetext{
${ }^{11}$ ROUSSEAU, Jean-Jacques. Les rêveries du promeneur solitaire. In: Idem. Oeuvres complètes, t. I. Paris: Gallimard, 1959, p. 1047.
} 
ali - desde que seja lícito esperar que se encontre - o exemplo de vida sem peias? É possível, dentro do mundo que se habita, supor a existência de condições para o desfrute absoluto que a cultura condena?

Montaigne aventara a possibilidade dum gozo maior oferecido pela vida pré-civilizada, quando se pôs a examiná-la, até concluir que, face a face com a civilização, deparava-se um "mundo infantil" em plena efervescência, no qual se podiam descortinar as condições primitivas para a fruição da liberdade com que sonhava o homem de sua época. A partir de então, esse mundo adquiriu os contornos duma esfera de vida paralela, dotada dos pressupostos para o exercício duma vida mais feliz do que a até então provada. A admissão de sua possibilidade haveria de causar um grande impacto nas consciências humanistas instruídas na busca dum homem "novo", tal como o exemplarmente concebido por Pico em sua Oratio. E é preciso ressaltar que os fatos aptos a sustentar uma aventura do imaginário tal como foi levada a cabo por esses homens "renascidos" no reexame da cultura clássica provinham de relatos cujo crédito tornava-se tanto maior quanto mais contrastavam com o saber antropológico tradicional. ${ }^{12}$ Nesse sentido, podese dizer que, para eles, esses relatos contribuíram vivamente para reforçar a nota de descoberta original perseguida pelo movimento humanista ao qual pertenceram, particularmente por servirem à ideação do que veio a ser considerado o desvelamento do homem "novo" que inauguraria a visão do humano na modernidade.

As crônicas americanas contendo todo tipo de informação sobre a natureza do Novo Mundo haveriam efetivamente de fornecer variados motivos para os doutrinadores ávidos em reformar ou, ao contrário, robustecer o pensamento recebido. É comum notar-se a esse respeito que a sua apropriação, sujeita ao arbítrio das preferências pessoais, leva amiúde a reforçar um ou outro aspecto nem sempre condizente com a realidade observada. Todavia, ainda assim, nada as substitui quando se trata de conhecer pormenores do universo físico e humano americano. Isto porque os cronistas, como regra, eram educados numa tradição que há muito distinguia claramente entre a realidade e a fantasia, especialmente porque se incumbiam, via de regra, de redigir escritos com intenção historiográfica. Não se pode nunca esquecer que os relatos por eles produzidos forneciam elementos indispensáveis para uma correta tomada de decisão pelas autoridades às quais eram em geral

\footnotetext{
12 Exceto no que dizia respeito ao cristalizado na cultura em torno da Idade de Ouro do passado primitivo.
} 
destinados. Basta lembrar a propósito as Cartas de Colombo, a Historia general de las cosas de Nueva España, de Sahagún, ou o Tratado descritivo do Brasil, de Gabriel Soares de Sousa. ${ }^{13}$ Entre outros inúmeros exemplos de crônicas indispensáveis ao conhecimento da primeira América merece menção especial a carta Mundus Novus, de Amerigo (Alberigo) Vespucci, por contribuir para revelar aspectos fundamentais para a afirmação dum conceito de selvagem que haveria de gozar de imenso sucesso no imaginário do novo intelectual europeu que veio a se fazer uma espécie de arauto da modernidade. Nesta carta, este controverso perito em navegação, em sua terceira viagem ao subcontinente sul-americano, realizada em 1501, sob o patrocínio do rei de Portugal, d. Manuel, nos dá as suas impressões sobre as peripécias de sua aventura marítima, com destaque para as considerações sobre os indígenas americanos. Na narração que faz de sua circum-navegação pelo litoral do continente, Vespucci dedica uma parte à "natureza e costumes daquela gente", cujos ecos se farão sentir não só em seu tempo, mas também, presumivelmente, em épocas subsequentes. O trecho em questão fala de homens vivendo em condições que, desde a ilustração histórica promovida por Heródoto, não se viam tão próprias a despertar o assombro do civilizado, habituado, pela leitura da massa de conhecimento acumulado em torno do próprio homem, a não titubear diante de qualquer notícia, qualquer que fosse o seu teor. Eis algumas das características do selvagem apontadas por Vespucci:

01 - Os povos da América formavam "uma multidão de gente que ninguém poderia enumerar, como se lê no Apocalipse".

02 - Trata-se de "gente mansa e tratável".

03 - "Todos dum e doutro sexo andam nus."

04 - "Têm corpos grandes, sólidos, bem feitos e proporcionados."

05 - Eis como tratam os próprios corpos: “...perfuram as faces, os lábios, o nariz e as orelhas". Ornamentam os orifícios com "pedras cerúleas, marmóreas, cristalinas e de alabastro, belíssimas, e com ossos branquíssimos e outras coisas lavradas com artifício...."

06 - "As suas mulheres, sendo muito libidinosas, fazem inchar os membros de seus maridos a tal ponto que vêm a parecer disformes e brutais, e isto mercê dum certo artifício e da mordedura de certos animais peçonhentos; e por causa disto muitos deles o perdem e tornam-se eunucos."

07 - Seus costumes passam pelo desapego à vestimenta: “Não têm panos de lã, nem de linho, nem sequer de bombazina, porque de nada disso necessitam."

\footnotetext{
${ }^{13}$ Vide a respeito, por exemplo, LINDO, Luiz A. O Roteiro geral de Gabriel Soares de Sousa como texto de razão política. Língua e Literatura, v. 24, 2013.
} 
08 - "Não têm bens próprios, sendo todas as coisas comuns."

09 - "Vivem juntos sem rei, sem autoridade e cada um é senhor de si."

10 - "Tomam tantas mulheres quantas querem; e o filho se junta com a mãe, o irmão com a irmã, o primo com a prima e o desencontrado com quem encontra. Toda vez que querem desfazem o matrimônio, ninguém nisto observando ordem alguma."

11 - "Não têm igreja, lei nenhuma também não têm, nem sequer são idólatras."

12 - "Vivem segundo a natureza, e pode-se dizer que são mais epicureus que estoicos."

13 - "Não há entre eles mercadores ou mercado de coisas."

14 - "Os povos combatem entre si sem arte e sem ordem. Os velhos com certas perorações inclinam os jovens ao seu querer, incitando-os à batalha, na qual se matam com crueldade: e aqueles que na batalha são feitos cativos, não vivos, antes para seu alimento servem, por ocasião de sua morte; pois que os vencedores comem os vencidos, e das carnes a humana é entre eles alimento comum."

15 - "As suas armas são o arco e a flecha, e, quando se enfrentam na batalha, não cobrem nenhuma parte do corpo para se defenderem, assim que nisto se parecem aos animais."

16 - As mulheres “...nenhum defeito apresentam e seus corpos são formosos e limpos, nem tampouco são tão feias como talvez se poderia supor (...) Vivem 150 anos e poucas e raras vezes adoecem."

O indígena vespucciano retratado nos tópicos acima possui uma singularidade que talvez não pudesse ser apreciada devidamente no momento em que foi "apresentado" ao conhecimento da civilização. Com o passar do tempo, porém, ele ou uma sua versão muito próxima viriam a compor a figura de "selvagem" que fixou morada na imaginação do homem civilizado, especialmente na dos teóricos do homem natural que operaram no Iluminismo europeu. ${ }^{14}$ A nosso juízo, o "caso Vespucci" - se é lícito assim chamar a repercussão da Mundus Novus na cultura europeia - oferece, dentre todas as aproximações aplicadas na composição do protótipo teórico, a mais genuína e produtiva para a afirmação do "caso Rousseau" empreendida em torno da ideia de homem natural. A simbiose epistêmica entre o relato cronístico e a teoria do "bom selvagem" deve-se, a nosso ver, ao acúmulo de

\footnotetext{
${ }^{14}$ A recepção da figura do "bom selvagem" na filosofia do Iluminismo inglês e francês mereceu um estudo abrangente de HONIGSHEIM, P. The American Indian in the philosophy of the English and French Enlightenment. Osiris, 10, 1952, p. 91-108. Também relevante para se entender a recepção da América na Europa, desta vez nos quadros do humanismo, é a visão de FERRAÚ, G. La prima recezione del "mondo nuovo" nella cultura dell'Umanesimo. In: THE TENTH INTERNATIONAL CONGRESS OF NEO-LATIN STUDIES. Acta Conventus Neo-Latini Abulensis. Proceedings. Ávila, 4-9/8/1997, Arizona Center for Medieval and Renaissance Studies, Arizona, 2000, p. 29-39.
} 
características comuns observadas entre o protótipo de indígena investigado e descrito pelo navegador florentino e o conceito de homem natural formulado pelo pensador suíço. Sabe-se que Rousseau tinha vasto conhecimento da "literatura de viagem"15 que tantas impressões deixara na imaginação da intelectualidade europeia empenhada em rediscutir as bases duma cultura universal a partir duma definição de humanidade mais abrangente e ativa do que a até então oferecida pela cultura clássica e cristã.

No Discurso sobre a desigualdade, ao defender a tese da bondade original do homem, Rousseau assevera o princípio absoluto de que o homem é bom por natureza, sendo, em sua essência, infenso às mazelas do pecado original ou de outra possível nódoa moral. Essa ideia é basilar num pensamento que se quer revolucionário e destinado a fundar uma nova religião civil capaz de aniquilar o cristianismo, mormente na sua feição institucional operada por sacerdotes. Pregando a eliminação dos sacramentos manejados por um corpo eclesiástico com o fim de reconquistar pela unção da graça a pureza perdida com o pecado original, a nova religião rousseauniana terá no crente que abraça a fé por escolha própria, sem intermediários entre si e a divindade, o ápice da personalidade beatífica pronta a usufruir os benefícios da nova fé. ${ }^{16}$

G. Chinard defende que a ideia da bondade original humana fora recolhida por Rousseau através da leitura das crônicas americanas, um fato para ele incontestável. No seu entender, a teoria pode ser encontrada em germe naquele gênero literário, tendo-se desenvolvido nos escritores que nelas se inspiraram. Montaigne, Buffon, o abade Prévost, Lescarbot, Fénélon são alguns dos nomes citados pelo crítico francês que teriam contribuído para fazer da bondade do selvagem "um lugar comum nos relatos de viagem do século XVIII (...) Ela continua, no entanto, confinada nessa literatura um tanto especial, imersa numa mixórdia de pormenores dispensáveis até o dia

\footnotetext{
15 "A dívida de Rousseau para com os viajantes é dupla: cabe com efeito precisar o que ele imita e o que ele continua, entre as ideias que flutuam no ar no momento em que compunha seus Discours e os fatos mais ou menos exatos que certos viajantes cujas obras teve nas mãos podiam lhe fornecer." CHINARD, G. L'Amérique et le rêve exotique dans la littérature française au XVIIe et au XVIIIe siècle. Paris: Hachette, 1913, p. 342. O impacto da crônica americanista sobre outro grande filósofo foi notado por S. Landucci: “Neste nível pode-se dizer que todo viajante é uma fonte possível de Hobbes, já que todos tinham-se detido, com horror condescendente, naquele fenômeno [do conflito intertribal permanente] assaz aparatoso, e alguns tinham descrito amplamente as suas formas e características de crueldade e 'desumanidade'...' LANDUCCI, S. I filosofi e i selvaggi, 1580-1780. Bari: Ed. Laterza, 1972, p. 125.

${ }^{16}$ Sobre a religião do filósofo vide BURGELIN, P. Jean-Jacques Rousseau et la religion de Genève. Genebra: Ed. Labor et Fides, 1962.
} 
em que Rousseau imaginará descobri-la, e a apresentará nua e simples ao grande público".17

Dos cronistas que possam ter influenciado na criação da lenda do homem original americano, Vespucci casa com a precisão que se espera. Pois no homem americano vespucciano, como mostram os tópicos acima condensados da Novus Mundus, delineia-se um perfil de tipo humano no qual a variabilidade individual e de estágio civilizatório pode ser reduzida, por meio de abstração, à forma geral do "selvagem" voltado para a exploração hedonista do seu meio e como tal imune a todo e qualquer freio que lhe imponha o sacrifício esperado na edificação da vida civilizada. Por outro lado, o retrato do selvagem rousseauniano, confinado ao estado de natureza, voluntarista e mesmo um ser pré-racional, submetido à força da paixão, vivida imperiosamente, é em parte obtido por um exame interior, à maneira duma autorreflexão remotamente socrática, mas antes e sobretudo psicológica, como requer a concepção psicogênica da vida desde então em voga, e em parte por condensação imaginativa das notas individuais colhidas nos dados fornecidos por relatos cronísticos, como indica Chinard e que aqui se corrobora. Seria altamente improvável que Vespucci desconhecesse as discussões travadas no círculo erudito da Florença humanista de sua época, da qual nunca se afastou intelectualmente, como mostra a sua carreira de navegador que se orgulhava de possuir um largo conhecimento das técnicas e ciências, fundamentais para o bom desempenho de sua função. ${ }^{18}$

\footnotetext{
${ }^{17}$ CHINARD, G. Influence des récits de voyages sur la philosophie de J.-J. Rousseau. Publication of the Modern Language Association of America, 26, 1911, p. 492. Chinard parece inclinado a pensar que a leitura assídua de obras sobre a América aparecidas no século XVIII foi determinante na apropriação, por parte dos intelectuais da época, da lenda dum homem em estado puro vagando por terras americanas. Idem, p. 491. O precursor, Montaigne, teria sido, segundo ele, influenciado por A. Thevet e suas Singularités de la France Antarctique, de 1556 (Ibidem, p. 480, nota 2). Em nenhum momento este autor aponta uma associação com Vespucci e sua carta.

${ }^{18}$ Pense-se no imenso sucesso que aquela carta obteve quando de sua publicação: 1503. Esta data é tida como a mais provável para Vignaud (VIGNAUD, H. Americ Vespuce. 1451-1512. Paris: E. Leroux Éd., 1917, p. 6), que não passa adiante sem aduzir opiniões divergentes da sua. A carta conheceu várias edições latinas, alemãs, holandesas, italianas, francesas, inglesas, espanholas e portuguesas ao longo do tempo. Doze delas vieram à luz já nos primeiros anos do século XVI. Vignaud lembra que a Novus Mundus teve mais reimpressões do que a primeira carta de Colombo (Idem, p. 157). Depois dela, a fama de Vespucci elevou-se tanto que o cartógrafo alemão M. Waldseemüller e seus colegas do Ginásio Vosgiano sugeriram batizar o Novo Mundo com o prenome de Vespucci, Americo, independentemente de a sugestão ter sido acertada, tendo em vista a controvérsia que suscitou, a partir da dúvida, sustentada por alguns, quanto ao verdadeiro prenome de Vespucci corresponder efetivamente ao que foi promovido e homenageado e quanto a ser o prenome a real fonte de inspiração. Uma alentada bibliografia registra a dis-
} 
Seria igualmente pouquíssimo crível que Rousseau não tivesse levado em conta, na construção do "bom selvagem", os dados que a literatura punha à disposição acerca do indígena encontrado na América.

O elo possível de se estabelecer entre a Novus Mundus e o conceito de homem natural rousseauniano é reforçado pelas convergências entre as supostas características do indígena reveladas na carta e os atributos reais identificados na natureza humana pelo filósofo. Rousseau encarou o problema de desvendar o caráter do primeiro homem como necessário na consideração das razões pelas quais, como ele se pergunta no Contrato social, "o homem nasce livre, e por toda a parte encontra-se a ferros"; ou, como proclama no Discurso sobre a desigualdade, por que se orgulhava de ter chegado ao conhecimento do estado de natureza como nenhum outro filósofo o fizera antes dele. Seu olhar sobre o que afirmava ter conhecido como ninguém ele assim o descreve: “...vejo um animal menos forte do que uns, menos ágil do que outros, mas, em conjunto, organizado de modo mais vantajoso do que todos os demais (...) Vejo-o satisfazendo a todas as suas necessidades". Um ser apto a satisfazer as suas necessidades, mas não completo ou em vias de completar a sua natureza, corresponde ao homem natural que domina a cena do Discurso. Trata-se do ser metido no estado de natureza, o qual pode ser descrito como

cussão. Seis exemplos disso: GARRILLO Y ANCONA, G. Estudio filológico sobre el nombre de América y el de Yucatán. Yucatán, 1890; PALMA, R. Tradiciones peruanas. Barcelona: Montaner y Simón, 1893; ST. BRIS, T. de. Discovery of the name of America. Nova York, 1888; MARCOU, J. Nouvelles recherches sur l'origine du nom d'Amérique. Paris: Soc. de Géographie, 1888; HURLBUT, C. The origin of the name "America". Journal of the American Geographical Society, XX, 1888, p. 183-196; e ARCINIEGAS, G. Amerigo y el Nuevo Mundo. México: Hermes, 1952. Quanto à autenticidade da autoria da carta Mundus Novus por Vespucci, uma obra recente procura resumir o estado da questão, sujeita a discussões infindáveis na literatura especializada, não sem deixar de contribuir com a própria opinião, aliás predisposta a dar fé à tese da legitimidade da autoria do documento pelo navegador florentino: "Nenhum dos argumentos, afirma o autor, contra a autenticidade de Mundus Novus convence. Não se trata duma obra veraz, já que inclui a colaboração feita por outras mãos, tais como possivelmente a dum tradutor jovial, ou de outros membros dum corpo editorial. Nos lugares onde se afasta dos relatos manuscritos das viagens de Vespucci, as divergências parecem calculadas com olhos no mercado, mas ainda assim é um produto cujas origens o aproximam da própria obra de Vespucci, sendo totalmente representativa do restante de sua oeuvre autêntica. Ela é, para empregar uma expressão de Luciano Formisano, 'não pseudovespucciana, mas paravespucciana'". FERNÁNDEZ-ARMESTO, F. Amerigo, the man who gave his name to America. Nova York: Random House, 2007, p. 100. Sobre a educação científica de Vespucci, leia-se, de LESTER, C. E. \& FOSTER, A. The life and voyages of Americus Vespucius; with illustrations concerning the navigator and the discovery of the New World. New Haven, 1853; também FERNÁNDEZ-ARMESTO, op. cit., embora este autor julgue com cautela os predicados científicos de Vespucci. 
...o reino da sensibilidade, da inocência, da simplicidade, da ignorância; é também, se se crê na Nouvelle Héloïse, o da espontaneidade e da profundidade da paixão; enfim, é o egoísmo instintivo, que impele o homem a conservar seu ser, a satisfazer suas necessidades sem fazer mal a ninguém, sem nada tomar além de seu bem; é uma simpatia e uma piedade que o levam a ajudar o seu semelhante. Este estado, anterior ao bem e ao mal propriamente ditos, já que a moral e a lei não existem ainda, pois é impossível pecar contra elas, é em suma a inocência do animal. Que sobrevenha a seguir a sociedade, a razão, a reflexão etc., e este egoísmo inofensivo e pleno de frescor dará lugar ao interesse implacável e injusto, à discórdia, à miséria, à corrupção. ${ }^{19}$

Não é preciso muita imaginação para associar a possibilidade de tais condições de vida às que cercam o selvagem vespucciano. ${ }^{20}$

A análise do homem, quer seja efetuada sob o ângulo de sua essência, quer sob a do seu estado de natureza, implica em Rousseau uma rejeição do conceito de homem firmado na filosofia clássica e na teologia. É lícito pensar que os pressupostos para a nova visão rousseauniana devem encontrar-se primeiramente no humanismo, em conformidade com o interesse maior revelado neste movimento por instaurar uma nova definição de homem, em contraposição às tradicionais clássica e teológica, tendência discernível no exemplo da Oratio piquiana acima mencionada e que haveria de confluir, como se infere, para uma metafísica de feição naturalista. ${ }^{21}$

${ }^{19}$ GUEROULT, M. Nature humaine et état de nature chez Rousseau, Kant et Fichte. Revue Philosophique de la France et de l'Étranger, t. 131, nº 9-12, 1941, p. 385. Cf. ROUSSEAU, Jean-Jacques. Discurso sobre a origem e os fundamentos da desigualdade entre os homens. Tradução de L. S. Machado. São Paulo: Abril Cultural, 1973, p. 247.

${ }^{20}$ O homem completo, ao contrário, só poderá ser conhecido no limite máximo de sua perfeição, tal o homem civilizado representado no Contrato social, aquele que, após o pacto fundador da sociedade, encontra-se em plena trajetória de desenvolvimento, realizando o seu potencial de perfectibilidade. Este é propriamente o homem essencial, nascido livre e aspirando a viver sob a lei estabelecida sob a vontade geral, enquanto o homem real do Discurso apresenta-se mergulhado no estado de natureza primevo. É preciso reconhecer, porém, o apontado por S. Landucci, ou seja, que, para Rousseau, não deve haver confusão entre o selvagem do Novo Mundo, que vivia numa "situazione di società", e os "uomini di natura". Na doutrina do segundo Discurso, nota Landucci, "a separação selvagens-'homens naturais' torna-se totalmente necessária, e óbvia, uma vez constatada, por Rousseau, a crueldade sanguinária própria dos 'peuples sauvages' descobertos nos tempos modernos, documentada por todas as crônicas". LANDUCCI, S. I filosofi e i selvaggi, 1580-1780, op. cit., p. 368. A mesma observação é feita por G. Gliozzi: “...o selvagem de Rousseau não é o homem natural originário, mas o resultado dum processo histórico deveras longo". GLIOZZI, G. Differenze e uguaglianza nella cultura europea moderna, op. cit., p. 367.

${ }^{21}$ Vide a respeito GENTILE, G. Il concetto dell'uomo nel Rinascimento. In: Idem. Il pensiero italiano del Rinascimento. Florença: Sansoni, 1940. 
Rousseau, como operador eminente nessa linha de pensamento, anseia por uma síntese que resolva duma vez por todas o conflito entre uma visão de homem ainda marcada pela tradição teológico-filosófica construída levando em conta a possível ordenação divina da vida, incluindo o que toca ao homem, e um pensamento que, levado ao seu extremo, procurava introduzir a ideia duma moralidade fundada em pressupostos naturais, enquanto obra de um animal dotado de um potencial para aumentar o seu domínio sobre o mundo, por meio de uma ação alicerçada na crença em uma liberdade absoluta. Rousseau parece ter percebido que esse conflito, tratado por ele como uma contradição entre a liberdade do indivíduo e a coerção exercida pela sociedade organizada para favorecer poderes discricionários, desde que não resolvido adequadamente, constitui uma ameaça perene ao que entende ser fundamental para a boa vida. É por possuir uma dignidade natural à altura de sua liberdade que o homem se mostra capaz de superar as mazelas da vida social que o forçam permanentemente a se fazer o algoz de seu semelhante. Para levar adiante a sua visão de metafísico naturalista, Rousseau precisava repropor o problema do homem, qual seja o do conflito entre o indivíduo e a sociedade, o que o levou a forjar um conceito de humanidade donde poder afirmar sem equívocos uma universalidade humana à prova de intermediários dotados de representação social concorrente com o espírito da vontade geral encarnada no Estado, eleito pelo filósofo o representante último da cidadania. Para tanto servirá a sua síntese do humano formulada por meio das noções de homem natural e de estado de natureza. ${ }^{22}$

Sobressaem dessa síntese as muitas semelhanças com a descrição encontrada na literatura etnográfica surgida a partir do século XV. Embora nenhuma delas se case tão bem como as que nos propõe a carta Novus Mundus, a notável afinidade entre o relato vespucciano, supostamente sustentado em fatos, e a ideia de homem natural rousseauiana, concebida para servir de parâmetro para uma crítica desencantada do homem civilizado, como requer a episteme do filósofo, esbarra todavia num duplo problema. Primeiro, há dúvida se o relato de Vespucci pode ser considerado fidedigno e como tal fornecer elementos a uma definição de "selvagem" suficientemente embasada em fatos. O próprio Rousseau, não obstante, como se depreende, ser muitíssimo lido em etnografia americana, afirmou não se basear em relatos para pensar o "selvagem":

\footnotetext{
${ }^{22}$ Sobre as contradições em que recaiu ao trilhar esse caminho vide GUEROULT, M., op. cit., particularmente na parte que trata da crítica de Fichte à ética do filósofo suíço.
} 
Que meus leitores não pensem que ouso iludir-me julgando ter visto o que me parece tão difícil de ser visto. Iniciei alguns raciocínios, arrisquei algumas conjecturas, antes com intenção de esclarecer e de reduzir a questão ao seu verdadeiro estado do que na esperança de resolvê-la. Outros poderão, desembaraçadamente, ir mais longe na mesma direção, sem que para ninguém seja fácil chegar ao término, pois não constitui empreendimento trivial separar o que há de original e de artificial na natureza atual do homem, e conhecer com exatidão um estado que não mais existe, que talvez nunca tenha existido, que provavelmente jamais existirá, e sobre o qual se tem, contudo, a necessidade de alcançar noções exatas para bem julgar de nosso estado presente. ${ }^{23}$

Rousseau com essas palavras afasta de seus objetivos na busca do estado de natureza humano os dados concretos à disposição. Ele toma o cuidado de rejeitar "todos os fatos, pois eles não se prendem à questão", quais sejam, "as verdades históricas", para em seu lugar privilegiar os "raciocínios hipotéticos e condicionais, mais apropriados a esclarecer a natureza das coisas do que a mostrar a verdadeira origem e semelhantes àquelas que, todos os dias, fazem nossos físicos sobre a formação do mundo". ${ }^{24}$ Perora essa parte com uma advertência feita em tom sombrio:

Oh! homem, de qualquer região que sejas, quaisquer que sejam tuas opiniões, ouve-me; eis tua história como acreditei tê-la lido não nos livros de teus semelhantes, que são mentirosos, mas na natureza que jamais mente. Tudo o que estiver nela será verdadeiro; só será falso aquilo que, sem o querer, tiver misturado de meu. Os tempos de que vou falar são muito distantes; como mudaste! É, por assim dizer, a vida de tua espécie que vou descrever de acordo com as qualidades que recebeste, e que tua educação e teus hábitos puderam falsear, mas que não puderam destruir. Há, eu sei, uma idade em que o homem individual gostaria de parar; de tua parte, procurarás a época na qual desejarias que tua espécie tivesse parado. Descontente com teu estado presente, por motivos que anunciam à tua infeliz posteridade maiores descontentamentos ainda, quem sabe gostarias de retrogradar. Tal desejo deve constituir o elogio de teus primeiros antepassados, a crítica de teus contemporâneos e o temor daqueles que tiverem a infelicidade de viver depois de ti. ${ }^{25}$

Neste trecho, a referência a uma época anterior lembrada com nostalgia, na qual é exaltado o primitivismo, como nas celebrações antigas da Idade de Ouro, confronta-se com a menção ao presente amargo e ao futuro ameaçador. É a ciência calando a boca da poesia, num discurso ao mesmo tempo

\footnotetext{
${ }^{23}$ ROUSSEAU, Jean-Jacques. Discurso, op. cit., p. 234-235.

${ }^{24}$ Idem, p. 242.

${ }^{25}$ ROUSSEAU, Jean-Jacques. Discurso, op. cit., p. 234.
} 
eloquente e premonitório, que imita o pensar e o discursar dos humanistas de outros tempos.

O segundo problema, decorrente do primeiro, leva a perguntar se é lícito considerar uma antítese do homem civilizado a partir duma construção intelectual assumidamente com mínimo caráter de evidência. Kant já examinara esse ponto e concluíra pela impropriedade de assim fazer. Eis o que ele diz: "Rousseau procedeu de maneira sintética e partiu do homem natural, eu procedo de maneira analítica e parto do homem civilizado". ${ }^{26}$ Kant está afirmando com isso que a essência da moral humana não pode ser procurada no homem natural tal como o concebia Rousseau no Discurso, mas apenas no homem civilizado, o único a dar causa a fenômenos observáveis aptos a servir de base para representações fidedignas do humano, universalizáveis num conceito genuíno de homem. Para Kant, faltam notas na concepção do homem natural rousseauniano que impedem asseverar com certeza que se trata do ser assim chamado e como tal reconhecível por todos. ${ }^{27}$ Operar com a possibilidade de o homem natural rousseauniano existir implica cair numa metafísica débil. Rousseau, como vimos, tinha consciência da fragilidade em se admitir o "selvagem" como ente de fato, sujeito de proposições verdadeiras. Precisava dele, porém, para dar forma ao que ele mesmo denominara "ciência natural" do homem. ${ }^{28}$ Para chegar à substância do humano resolve partir do que entendia haver de mais fundamental capaz de esclarecer o seu nascimento como ser natural. Para tanto, diz ele, é preciso olhar para "dentro" de si mesmo, pôr-se a investigar os sentimentos mais entranhados que permitam dar conta do humano. O que está fora nessa via de elucidação da gênese do homem natural deve, portanto, ser descartado. Pode-se ver

\footnotetext{
${ }^{26}$ Immanuel Kant's Sämmtliche Werke. In: HARTENSTEIN, William G. Chronologischer Reihenfolge. Leipzig: Leopold Voss, 1868, v. 8, p. 613.

${ }^{27}$ Para Kant, o homem natural não difere do homem essencial, tal como se dá a conhecer em sua existência, vale dizer, oposto ao animal, por sua razão teórica e prática. Além disso, este, que é também o homem real, é por natureza mau, fato que merece uma longa exposição em KANT, Immanuel. Die Religion Innerhalb der Grenzen der Blossen Vernunft. Leipzig: Felix Meiner, 1922, onde se pode ler: "A tese 'o homem é mau' não pode querer dizer, de acordo com o que precede, outra coisa senão que: o homem dá-se conta da lei moral e, no entanto, admitiu em sua máxima o desvio ocasional em relação a ela. (...) podemos pois chamar a esta propensão uma propensão natural ao mal, e, visto que, no entanto, há de ser sempre por si culpado, poderemos chamar a ela mesma um mal radical inato (...) na natureza humana" (p. 33).

${ }^{28}$ Em Rousseau juge de Jean-Jacques, ele se descreve a si mesmo como "historien du coeur humain". ROUSSEAU, Jean-Jacques. Rousseau juge de Jean-Jacques. Etudes sur les Dialogues 1. In: Idem. Oeuvres completes. Paris: Gallimard, 1959, t. 1, p. 728. E no Discurso, p. 243, já assinalado acima, apresentara-se a si mesmo como alguém que escreve a verdadeira "história" da natureza humana.
} 
que o que ele busca pressupõe um método parecido com um cálculo, em que a relação adequada entre as quantidades numéricas permite chegar ao resultado, não sendo este mais do que a expressão justa daquela relação. A definição do homem natural rousseauniano alcança-se igualmente a priori mediante a afirmação da qualidade substancial dos atributos humanos e sua imediata assimilação ao "selvagem", sem considerar se tais propriedades pertencem igualmente ao existente concreto. Estas propriedades, que são conhecidas a posteriori, são descartadas por nada acrescentarem à compreensão da essência do humano.

Por outro lado, ao mesmo tempo em que nega em parte as notas do homem civilizado como substanciais na definição do humano, Rousseau, que pretende ensinar a humanidade a se ver a si mesma sob novas luzes, ou seja, a se ver como verdadeiramente é, apreende o homem através de sua história, expressa no princípio de alteração das formas de vida de acordo com as condições sempre cambiantes. Como resultado da mudança sofrida pelo homem nas circunstâncias que fazem a sua história, estabelece-se uma distância entre o homem real e o homem essencial, a qual tende a ser maior à medida que avança o tempo que produz a civilização. Esse distanciamento é tratado no Contrato social como um golpe fatal na liberdade original, ${ }^{29}$ cujos efeitos se fazem sentir na necessidade de redefinir a natureza humana a fim de incorporar no conceito de homem a condição atual da vida em sociedade e como consequência pensar na liberdade não mais apenas como um atributo natural, mas agora também como uma característica da vida civil. Esta transformação na definição do humano ocorre de par com a introdução do método histórico como forma legítima de apreender o humano, o que não condiz inteiramente com a versão genética de interpretação da essência humana antes defendida no Discurso. A variação na perspectiva pela qual Rousseau enxerga o homem introduz um dualismo epistemológico. Pode-se dizer que um viés ora "romântico", ora "realista" passam a conviver na tarefa de dar conta da dupla visão do humano representada nas concepções da natureza do homem e do seu estado de natureza. O primeiro leva o pensador a buscar a suposta natureza do homem na sua "matéria" básica, identificada com a sensibilidade e a pré-racionalidade; o segundo leva-o ao momento atual, quando o homem, após um longo peregrinar histórico que na "sociologia" rousseauniana acarreta evolução, acha-se em pleno cumprimento de

\footnotetext{
${ }^{29}$ Está ali dito: "O homem nasce livre, e por toda a parte encontra-se a ferros". ROUSSEAU, Jean-Jacques. Do contrato social. São Paulo: Abril, 1973, p. 28.
} 
seu destino de ser racional mergulhado na constante criação e solução dos inúmeros problemas a que o impele a sua intensa vida social. Ao oscilar na explicação para a natureza do homem entre a origem genética ou interna, como vimos, e a transformação qualitativa operada por causas históricas ou externas, Rousseau deixa abertas duas possibilidades para o conhecimento e sobretudo para a ação do homem. Na primeira, há o convite a levar ao infinito a exploração da caverna interior identificada com a psiquê individual; na segunda, apela-se ao poder das ciências e das artes em investigar, a partir dos conceitos e das imagens do humano representativas da cultura expressiva das formas de vida social, o modelo mais adequado para o exercício do governo político. A figura do homem natural, ou seja, imerso no estado de natureza, ilustrada exemplarmente pelo selvagem vespucciano, representa o arquétipo do habitante insondável da caverna interior; a figura do homem livre por natureza, permanente em sua essência, porém apanhado na armadilha da sociedade e em luta constante por conquistar o máximo de liberdade civil, representa o arquétipo do cidadão propenso à reforma política destinada a criar, na imaginação do filósofo, o homem novo. 